\title{
Gender Identity Change in a Female Adolescent Transsexual
}

\author{
Charles W. Davenport, M.D., ${ }^{1,3}$ and Saul I. Harrison, M.D. ${ }^{2}$
}

\begin{abstract}
Two years of individual and milieu therapy are described of a 141/2-year-old girl who had presented with the persistent request to have a sex-change operation since age 12. Her past history was obtained from her parents and the records of the child guidance clinic which evaluated her at 3 years of age. She gives a history of remarkable tomboyism during her latency years and increasing withdrawal from peers and family during early adolescence. The patient's personal and family dynamics are explored, and these major therapeutic themes are discussed. The individual and milieu therapy are described and discussed with some speculation about the reasons for her positive response to psychotherapy. It would appear that this is a rare case of a postpubertal female transsexual reported to have made a gender identity change.
\end{abstract}

KEY WORDS: adolescent; transsexual; individual psychotherapy; milieu therapy; gender identity.

\section{INTRODUCTION}

This article is a unique report of the successful change in gender identity of a postpubertal female transsexual. While the criteria for a decision to undertake anatomical sex change have been delineated and the results of such surgical transformations are on the whole reported as positive, the literature about psychological and pharmacological treatment of adult and adolescent transsexuals is almost uniformly negative (Pauley, 1969; Baker, 1969). The two exceptions

\footnotetext{
${ }^{1}$ Clinical Assistant Professor in Psychiatry, University of Michigan Medical School, Ann Arbor, Michigan.

${ }^{2}$ Professor of Psychiatry, University of Michigan Medical School, Ann Arbor, Michigan.

${ }^{3}$ Address correspondence to Dr. Charles W. Davenport, Department of Psychiatry, Medical College of Ohio, P.O. Box 6190, Toledo, Ohio 43614.
} 
are the report by Barlow et al. (1973) of the successful treatment of a 17-yearold male transsexual by behavioral modification techniques and Dellaert and Kunke's (1969) report of using analytic psychotherapy to successfully treat an adult male transsexual.

"Transsexual" is a relatively recent term used to describe a biologically normal person who identifies himself or herself psychologically as a member of the opposite sex. The transsexual is usually identified as such when he or she seeks surgical transformation in an effort to make the body congruent with identity and to enable a "normal" life pattern in the sex of identity (Benjamin, 1966). Female transsexualism is manifested by profound and normal-appearing masculinity in an anatomically normal female. The female transsexual maintains that she has always viewed herself as masculine. The transsexual typically expresses a strong aversion to homosexuality, and indeed the idea of being attracted to an overtly heterosexual female seems necessary to support the self-concept of maleness (Green, 1974).

Since an accurate diagnosis and differentiation from transvestism and homosexuality are essential (Green, 1970; Newman, 1970), especially for a decision to undertake sex-change surgery, efforts have been made to make the diagnosis more definitive. Stoller's (1972) criteria are among the more specific and include the following: (1) at birth the female infant is unequivocally assigned to the female sex; (2) the parents do not question that she is a girl; (3) the girl begins to demonstrate masculine interests and behavior by 3 or 4 years of age; (4) during latency the girl plays with boys' toys, walks and talks like a boy, and has developed unusual sport skills; (5) the person states openly that she will be a boy when she grows up; (6) puberty with menstruation and development of female secondary sex characteristics makes her more insistent on being allowed to dress and to be treated like a boy; (7) by late teens or early adulthood the transsexual will have "passed" and been accepted as a male by a group that does not know "him" to be female; and (8) the patient will then seek sex transformation procedures, often being quite insistent. Stoller noted that there is no episode of clear feminine development; the masculinity seems to be primary and not secondary to rejection of femininity.

The medical literature offers a wide variety of organic and psychogenic etiological theories. None has been tested and established. The etiological theories that can loosely be called "organic" hold that structural or biochemical abnormalities in the brain are the cause of transsexuality (Blumer, 1969; Gadpaille, 1972; Hoenig and Kenna, 1974; Walinder, 1965).

The psychological theories of causation are diverse. Money et al. (1957) suggest that an imprinting process takes place during the first 2 or 3 years of life which determines the gender identity of humans. Stoller $(1968,1972)$ takes a dynamic approach and describes the family etiological factors for female transsexualism. Other authors have expressed the view that transsexualism is a defensive reaction to homosexuality (Socarides, 1970). 
The transsexual is faced with unique problems. This is particularly true during adolescence (Newman, 1970). The adolescent transsexual is in conflict internally because of unwanted pubertal changes and is also in conflict with parents and society, who oppose cross-gender apirations. The adolescent may become depressed or may run away unless support comes from parents or professionals. Since there are reports of improved psychological states when patients were allowed to live in their cross-gender role, it is tempting to consider supporting such behavior when one sees adolescents in such obvious distress.

\section{CASE HISTORY}

This article reports 2 years of individual and milieu therapy, beginning at age $14 \frac{1}{2}$, of a girl who had announced to her parents when she was 12 that she wished to have a sex-change operation. She had been tomboyish through her latency years. With the onset of puberty, she had begun to refuse wearing dresses and had begun to withdraw progressively from her peers and to deteriorate in school performance.

The child was second in a sibship of four. A brother, 3 years older, was a successful student; a sister, 1 year younger, was "tomboyish"; and the fourth child, the only planned child, was a "friendly, outgoing, and successful" girl, 3 years younger.

The parents had been married 18 years at the time of the patient's evaluation. A longstanding history of marital difficulties had come to a turning point 3 years previously, when the father had the mother committed to a psychiatric hospital on an emergency basis. She had remained only overnight and had continued with psychiatric therapy since that time. The mother appeared to be a tense, insecure person with little self-esteem and an apparent history of lifelong depression. By the time we saw the family, the mother was able to see her marriage as never a good one, and as her psychological situation improved she was able to see how she had assumed the blame for all marital problems. She noted that she had an early history of being a tomboy and that she did not date until 16 years of age.

The father appeared as a reasonable and patient, long-suffering husband. At the time the family initially was evaluated, they both supported this view of the father. To support this notion of his infallibility, the mother was constantly perceived as the cause of all problems and difficulties which came up in the family, a role which she had readily accepted for years. The father was well defended and insensitive to his own interaction with the family. Indeed, he was generally psychologically and physically absent from the family. Most of his interests were outside the home with male friends or in isolated activities. Although he talked about being a warm and supportive parent, in reality he was isolated and self-centered. 
The patient was the product of an unplanned but "welcomed" pregnancy. The pregnancy and birth were without complication - a "normal and healthy girl." Her mother suffered from postpartum depression for approximately 3 months. The infant was breast fed for a few weeks and then placed on a bottle, often propped. Although she was weaned at 13 months, she returned to using a bottle at 18 months when her sister was born, and she continued to do so until approximately age 2 .

The patient had been seen at a child guidance clinic at age 3 years because of head banging, hair pulling, and excessive demand for maternal attention. She was also described as not liking to be held. An impression from the early history is of a needy child desperately seeking intimacy from a mother who was depressed, withdrawn, and empty. The father at the time of the early child guidance evaluation was perceived as a source of warmth and support for the child and her mother, but in reality he was absent from the home much of the time. There was a singular note in those early child guidance clinic records that reflected sexual development: "[The child's] head was shaven [as a treatment for the hair pulling] and while some of the hair was growing back she looked more like a little boy with a crew cut than a little girl."

Although she had a history of seeking excessive amounts of attention from her mother early in life, she was able to master the separation of nursery school and grade school without apparent difficulty. Tomboyish behavior was apparently tolerated and/or supported by both parents.

The extended evaluation prior to hospitalization was done by a psychiatrist who had had considerable experience with transsexual patients and had participated in the development of a gender clinic. The length of the evaluation stemmed from a combination of the patient's extreme inhibition and the psychiatrist's hesitation to recommend psychotherapy for a transsexual adolescent in the face of the negative experience and literature, and the difficulty in locating an appropriate therapeutic program.

During the evaluation, the patient convincingly presented herself as a boy in dress, voice, movement, interests, and orientation. Her approach to the initial interview was guarded. Reality testing outside this area was good, and she showed no evidence of a thinking disorder. There was constriction of both thinking and affect. Intelligence was in at least the bright average range. She expressed herself eloquently in a letter written to the psychiatrist during the evaluation:

I want to be a boy more than anything in the world. It just doesn't seem fair to me to have been born the wrong sex. I think I'm just as normal as any 14-year-old boy mentally. I do an awful lot more thinking or dreaming than anyone I know. Maybe that is because I don't know what is going to become of me later on. I know perfectly well myself that I should have been born a boy and I should have my sex changed but I just don't know how to convince other people that I'm right. I never have talked much about it until just a few years ago to my parents. I remember about the second grade when my classmates asked me why I acted like a boy. I told them I felt I was a boy. I never talk to any adult about.it since no adult knew how I felt until a few years ago. I remember very well the times I insisted on wearing boy's clothes and getting my mom so shook up she would 
cry. Then my father would give me a look like I committed a crime. That is when I felt more alone than ever. I would just go to my room and sit and think and wish how much I were a boy. I just figured life was supposed to be mixed up, confusing, depressing, and miserable. I think the only way to change my sex is to have a lot of operations. I don't care how many it takes. I just wish it would be done. I could start living a normal boy's life.

The patient had a unique solution to her situation which she adamantly pursued in the course of diagnostic interviews. She saw people in the entertainment field as being able to accept people like herself, and would be a pop singer like a particular male entertainer with whom she identified. By the time of evaluation she had already withdrawn from sports and other activities with boys and peers. In an isolated and private manner, she practiced music and listened to records. In the course of evaluation she passively accepted the interpretation that her transsexuality might represent some unconscious conflict about her feminine body or female clothes. She therefore did not resist the idea of therapeutic effort to understand herself which might be useful whether she proceeded with her sex-change operation or changed her psychological sex to fit her female body. The evaluators felt that even if the psychiatric therapy did not result in a basic change in sexual identity the psychological adjustment to surgical change would be facilitated.

In accordance with those treatment goals, the patient was admitted to an inpatient psychiatric hospital for adolescents, where she remained for 20 months. In the hospital she was involved in triweekly, individual psychotherapy with a male therapist and milieu therapy. The milieu therapy included active intervention by psychiatric nurses and aides, therapeutic school, recreational therapy, and occupational therapy geared specifically toward adolescents. The patients admitted to this service manifest a wide variety of adolescent pathology. Approximately two-thirds of the patients are short-term admissions and one-third remain in residential treatment for prolonged periods of time. During the initial part of this patient's hospitalization, the psychotherapy and milieu management were done by the same person. Soon, however, it became clear that the patient was spending much of the individual therapy time talking about ward problems and bargaining for privileges. Therefore, after about 3 months, a different person was assigned to manage the milieu and psychotherapy was relatively isolated from milieu management. The parents were seen individually on an intermittent basis to enlist their support of the patient's treatment and management.

The first 2 months of hospitalization were stormy. She was guarded and distrustful during this stage. The most striking thing about her was her male presentation. She had dressed as a boy since her school had dropped its ban on slacks 3 years previously, and on many occasions she wore shirts to hide her developing breasts. Her interests were traditionally masculine and her uninterest in feminine activities was obvious. She would respond with delight when someone referred to her as a boy and with anger or embarrassment when referred to as a girl. Her severe social withdrawal was striking, and she spent much of the time in her room avoiding both staff and other patients. 
At the same time, the psychotherapist was struck by her severe constriction of thought. She had a hard time elaborating on any idea even when the subject was neutral or pleasant. There seemed to be a quality of stubbornness demonstrated in her refusal of hospital activity and withholding of information in interviews. When first admitted, she refused to eat, and seemed to be using this to pressure her parents to sign her out of the hospital. Signs of anxiety, however, were also clear, and weeks later she was able to acknowledge in psychotherapy that she was scared and did not have any appetite.

One of the first issues the patient began to examine in psychotherapy was her family and its interactions. After her father disappointed her on two occasions by not showing up for visits, she appeared angry. Confronted with her anger, she agreed that she was very disappointed and that it was not infrequent for Dad to have good intentions but somehow never follow through. She added that it never turned out to be his fault. Her mother was the one who was usually held responsible and became the recipient of the blame and anger from both the father and the other children.

Her earliest memory of conflict over "sexual" matters was in nursery school. She wished to wear slacks, but her mother always forced her to wear a dress. In retrospect she could not remember why she wanted to wear slacks except perhaps to play on the monkey bars. Similar conflicts continued in kindergarten, when her mother would approve slacks outdoors in the winter, but insisted that they be taken off in class. She remembered being quite angry about having to wear a dress to school all the time. The second sexual topic was her misconception about the sex-change operation. Somehow she felt that it would make her a "perfectly normal boy." That meant the ability to become a father. She was genuinely disappointed when she heard that this was not the case, and it became clear, at that time, that the idea of sexual activity itself was not valued as much as the ability to conceive.

After 4 months of hospitalization, she began to talk about having a crush on one of the female ward staff. This was an extremely difficult topic for her, and it required several interviews to communicate about it. In relation to this, she had fluctuations of mood, saying that at times she felt very depressed and at other times happy. She also voiced concern that the staff member would be turned off by her sexual feelings and would not understand. In actuality, she did not describe genital feelings but a general state of excitement. At this point, she launched into an explanation that she was not really homosexual because she wanted her sex changed and she related to girls as a boy.

Christmas vacation again brought up the topic of family. She began talking about wanting to go home because it was more free there, not because she missed her parents. Once again there was bickering at home about plans for the holidays. She felt that her mother was to be the scapegoat again and that her dad would let her take all the blame. Although she talked negatively about her father at times like this, she would frequently vacillate and become depressed when the family did not want to do things the father's way. It became clear that 
her cross-dressing bothered her parents; for instance, she wore pants to church on Christmas Eve, which her mother was able to tell her she didn't like. Her father, on the other hand, was not openly angry, but said little. She noted that it was characteristic for her father to keep his feelings to himself and let her mother be the spokesperson.

In a very teasing manner she began to refer to personal daydreams and feelings, then refuse to elaborate on them. She talked also about being angry about being in the hospital, having to come to psychotherapy and not knowing what to say. The material about cross-dressing again arose. Her cousin was getting married and there was to be a formal party to which she was invited. However, she knew that this would entail wearing a dress. She marked her ambivalence by saying that one way to avoid the problem would be to run away and then be restricted to the ward. This led to an admission that she was not comfortable about herself sexually at this point. She still thought about being a boy trapped in a gir's body, but she was not so sure anymore. Although she continued her daydreams of becoming a famous male singing star, she now gave reasons why she couldn't aspire to this. Fame would mean that people would look into her personal life and find out that she was really a girl. Also, she really wasn't much of a singer, and she wasn't doing anything to achieve that kind of goal. After this revelation, she ran away from the hospital for several hours to "clear her head." The theme that hospitalization was punishment came up after her return.

Other patients were here for running away from home, taking drugs, stealing things, but she was here because of the way she felt about herself sexually. That was her bad thing.

The patient learned of her parents' separation from the psychotherapist. Her initial reaction was anger that she was not told directly by them. This was followed by many questions about what effect this would have on her, especially which parent she would live with and who would make the decision. She knew that her father had initiated the divorce action, but he had talked little about it to her. She felt that her mother had hoped pathetically that they would reconcile. She was obviously pleased when her mother began to accept the idea of divorce and stand up for herself. She expressed hope that she would live with her mother but did not want to take responsibility for making that decision.

Her sister's confirmation again brought up the dressing issue. The patient essentially made the decision to wear a dress on her own and simply announced it to her parents. She rationalized that it would be wrong not to wear a dress to her sister's confirmation, and became confused when confronted with the fact that she wore pants to church on other occasions. Her reaction to wearing a dress to the confirmation was to say it made her feel terrible. She stated that she was treated differently when she wore a dress, but she was unable to say what that difference might be.

She then returned to the hard line: there was no conflict, she just had gotten the wrong body, when was the therapist going to quit bugging her by keeping 
her in the hospital? She began missing appointments and only returned when her milieu manager said if she did not go to therapy she would lose privileges, including weekend passes. During one therapy session, she heard a small boy across the hall express his anger in clear profane language. She laughed and this brought up the fact that she vicariously enjoyed watching other patients act out anger although she couldn't let herself do any of those things. She also noted that while her special female staff friend used to be necessary for her to feel good, she was no longer depressed on her day off and had been interacting with the girls' patient group on the ward.

As her cousin's wedding approached, she continued to toy with means of avoiding attendance, e.g., declining the invitation or getting restricted to the ward. However, as the time came closer, she said it really was not right to refuse to go so late. Therefore, she would have to go, which would mean wearing a dress. In essence she was saying that the decision was not really made by her. On her return from the wedding, she told the therapist it had been a lousy weekend but that somehow the dress only seemed a small part of it. She hotly denied the observation that she did not seem so angry about having to wear a dress as she had in the past. It was about this time that is was noticed that she was wearing $T$ shirts without an overshirt, which made her developing femininity quite obvious.

Separation issues then dominated for several weeks. Her favorite female staff member was leaving, which aroused feelings of abandonment. She said that she wanted to leave the hospital when the staff member did, but her father would not permit it until she saw herself as a girl. She was further angered by the fact that her milieu manager would also be leaving; this combined with thoughts of the divorce caused her to become depressed and turn her anger onto herself. Once again she began to wonder about the real issues of the divorce and with whom she would live. On the one hand, she thought the court would never listen to kids. On the other hand, she hoped they would make the decision for her. Once again there was the assumption that she would live with her mother. There was some guilt that her father would be lonesome, but she really did not want to live with him.

Near the end of the first year of hospitalization, we had begun gradually to recognize feminine traits and to reinforce them. Her attempts to avoid being involved with the girls' group were confronted, and she was seemingly merging with that group. She began to discuss her changing attitude toward her parents. She described how she used to admire her father and identify with him up until 2 or 3 years ago. He seemed to be intelligent, friendly, and successful. However, she had began to see him as an excessively critical man who continually ran down her mother and made fun of other people. Her changing attitude toward him probably had begun 3 years earlier when her mother had been hospitalized for depression. The patient had gradually come to see that he never supported her 
mother but expected her always to please him. Therefore, she no longer wanted to grow up and be like him. Her mother, on the other hand, had become more positive in her estimation. She described her as a depressive nonentity until 2 or 3 years ago when the depressive sysmptoms became extreme. She admired her mother for facing her problems and getting therapy 3 years ago and saw her mother as a better and more promising person with whom to identify. In the past, she had thought all marriages were like her parents'; that is, a bitter experience in which mothers were blobs who did what they were told and fathers were successful and happy. Concurrent with her changing attitude toward the family, her schoolwork improved. This may have been related to directing her anger onto her father and not displacing it onto the school, which represented her father's domain as an educator.

Another important change was that she referred to the female staff member as a friend and not as someone she had a crush on. It seemed that after the staff member had left, the patient's feelings began to change. We became increasingly aware that the staff member was reluctant to see the patient as a girl. Around this time, ward staff commented increasingly on the fact that the patient looked more feminine. Indeed, she was beginning to have internal conflicts in the form of wondering what it would be like to be a girl. She began to confide that she was feeling mixed up about herself. Since she couldn't be a "real" boy, she wondered what it would be like to dress as a girl and how she might feel. She reflected that over the past year ward staff had complained about her wanting to wear a shirt over her $T$ shirts, but never stopped it. She guessed that they were afraid of her. However, now that she was dressing more like a girl, people seemed to notice her more. She talked admiringly of a male staff member who was not scared when she got angry in response to being called "Miss." Although she still wondered at times what it would be like to be a boy, she began to say it just didn't seem right to be called "Mr." She described having admiring feelings toward the male staff person and eventually stated that it was sort of a crush like she had felt with the female before. It was a feeling of excitement and wanting to be with him as much as she could. In retrospect, she realized she began having those feelings as much as 5 months before, but they had recently increased.

As she continued talking more positively about being a girl, she discussed the fact that she never did feel right wearing pants to church and that it somehow seemed "strange." When she went to her favorite singer's concert with her father, she came back describing him as big and good looking, sounding very much like a prototypical teenage girl. Some of her parents' ambivalence was apparent during this visit home. She had thought her mother would be pleased when she told her about having a crush on the male staff person but got little or no response. It became clear to her at that point that although her parents complained about her masculine identity they sometimes acted as though they wished she were not a girl. She had picked out her own dress for the concert and her mother made no 
comment, in marked contrast to the many complaints her mother had expressed about her wearing pants. Her father also said nothing at first, but later commented that he thought she looked good in a skirt. He also noticed that she was letting her hair grow.

With the termination of her relationship with the female staff person, she began to turn more toward other ward staff and started to develop a dependent relationship with male ward staff, teachers, and her therapist. She alluded to feminine fantasies about these adult males as she demanded more of their time and attention. She became depressed or fantasized running away if staff members were absent or too busy to see her. Feelings toward male staff were expressed initially in displacement, such as relaying patient gossip about the sexual implications of a male staff person spending much of the time with another female patient. Eventually she was able to talk about her own embarrassment when teased by patients about the time she demanded from "her" staff person. She talked about running away as a method of getting more attention. On the one hand, she could run away and avoid strong feelings toward the staff; on the other hand, running away would mean restriction to the ward and more attention from staff as they would be concerned about her. While she would avoid talking about fantasies, she could tell the therapist that kids who ran away sometimes had to be held down by staff when they returned and she thought they enjoyed it. She was able to recognize her own vicarious enjoyment of this even as she enjoyed seeing other patients being aggressive with staff.

She began to experiment with "feminine" behavior, and this was encouraged and supported by staff. There was a recognition of her asexual and ambivalent attitude toward her femininity but an expectation that she would eventually be a woman. In therapy her progressive acceptance of her femininity became a dominant theme. She described growing interest and confort with dressing as a girl. At times she shopped for her own clothes, but frequently her mother bought dresses for special occasions. She no longer experienced discomfort when dressed up and looked forward to receiving new clothes. She continued to rationalize wearing dresses ("I couldn't wear slacks to church" or "I couldn't wear pants to a good restaurant like that"). Shortly before discharge from the hospital she arrived at the interview wearing a dress. She was somewhat nervous and actively sought compliments and approval from the therapist. Reflecting on her early discomfort with dressing as a girl, she guessed she worried how he would respond to her being in a dress. At this point, she could recognize that in the past she sought acceptance for dressing like a boy. That spring she decided to buy a bathing suit for the first time in 4 years. She selected a two-piece bathing suit and commented that she no longer needed to wear a shirt to hide herself as she did in the past.

She was now able to look at her fantasies about her own sexuality in a superficial way, this often in a teasing, provocative manner. She had been aware for several months that she fantasized being a boy when she was home and a girl when she was in the hospital. She related these fantasies of being a boy to 
the times she felt rejected and depressed, and thus being a boy would bring her attention and approval. She referred to a dream about a "caveman society" in which the only clear detail that she remembered was that she couldn't tell the difference between the sexes of these people as they all had long hair and wore leopard skins. In accepting a definite identity for herself, it became clear that she was talking in terms of being a boy or a girl rather than a man or a woman. She knew she avoided thinking about growing up.

On a number of occasions she talked about liking young children and "having a way with them." She enjoyed babysitting at home on weekends and started to talk about working with young children who didn't have parents after she finished school. There was a striking maternal quality to her interest in children, but she denied that she had any thoughts of being married and having children at this time.

As plans were being made for her discharge from hospital, she anticipated that she would miss important people on the ward. She had come to feel like a part of the girls' group and was able to compare this to her earlier isolation and disdain for her peers on the ward when she was admitted. She felt that she no longer was dependent on ward staff to help her make decisions but would miss the relationship with them. As she reviewed her hospitalization, she remembered it was her mother who was responsible for initiating psychiatric contact. She also felt she could talk freely to her mother, while her father only wanted to hear "pleasant things."

The family did not support therapy after discharge from the hospital, and she drove several miles for therapy before terminating treatment 4 months later. Although she spent much of her time talking about the problems with the family, she communicated also that she had adjusted to her old neighborhood school. She was developing friends through the band and indeed referred to a boy at school who always teased her as someone who "seems to like me." Although she would allude to sexual fantasies about the male staff person, she did not wish to explore her feelings further.

After termination, there was no word from her for several months until she requested a letter of recommendation to a boarding school for her senior year. Since then she has come back intermittently to see her therapist. Two and one-half years after termination, she continues to dress in a most feminine manner and appears to have adopted a feminine identity. She has finished high school, worked for a year, and is currently a college student. Although she alludes to her interest in boys, there has not been any evidence that she is sexually active at 19 years.

\section{DISCUSSION}

We have described the successful psychotherapy of an adolescent female transsexual. The signs of this patient's transsexual identity appear to have been 
present from early life, but her transsexual wish became overt and critical with the onset of puberty. There is evidence of avoidance of female sexuality, including denial that her feelings toward women were homosexual. She had to deny the usual adolescent conflicts about sexual role and claimed adamantly that she had a boy's brain and a girl's body. She had for some time avoided wearing girl's clothes, and although she was unable to articulate her fantasies about this it seemed to represent avoidance of female sexuality.

The assignment of a male therapist to treat a female transsexual was made on the basis of availability of an experienced psychotherapist. The sex of therapist did not seem important in the early phase of treatment when her transference was ambivalent and dependent. It should be emphasized that treatment was technically difficult because of the patient's constriction of thought, repression of feelings, and extremely moralistic attitude. The first half of treatment went to forming an alliance with the patient to help her begin to feel free to struggle with adolescent issues. She was guarded and seemed to expect rejection in general and for her transsexual wish in particular. The therapist attempted to be an accepting individual who confronted the patient with her denial of the family situation and her repression of feelings. Later she expressed sexual feelings toward her therapist and other significant males, in displacement. Attempts to directly interpret sexual transference material were unsuccessful. In this respect, sexual transference issues were not fully resolved and were managed by supportive psychotherapy.

Understanding the family constellation was important to this girl's treatment. The mother's role in the family was that of a depressed, indecisive, and devalued woman who accepted the blame for all the family problems. The father was initially perceived by the patient as an idealized, masculine, capable, and long-suffering man. In reality, the father was psychologically and physically absent; his appearance of strength was based on degrading the mother and the maternal role. Certainly the patient's recognition of the true dynamics made identification with her mother more possible. It helped the patient take another look at the role of women and to see her parents' marital situation as pathological and not like that of most families.

The wearing of men's or women's clothing appeared to be the main focus of rebellion between the patient and her mother and remained an issue throughout treatment. Clothes seemed to have a magical sexual quality, almost as though she concretely believed that "clothes make the man." The mother, who appeared to share this belief with her, started struggling with her about clothes in nursery school. We did not know the mother sufficiently well to assess whether she truly shared the attitude, or whether the mother's focus on clothes served another purpose. It was striking that the mother, who had nagged her daughter so much about appropriate dress in the right place, did not express pleasure when she started to dress appropriately. 
The patient's naivete about the "sex-change operation" and her surprise that it could not make her a real potent male were focal points in treatment. This disappointment motivated her for psychotherapy and to consider changing her psychological identity to match her physical sexuality. To some this had the ring of a rationalization. That is, this new knowledge enabled her in the hospital to deviate without losing face from a position she had stubbornly maintained so long with her parents - the equating of sexual identity and clothing. Therefore, she could now participate in the therapy for her dread of femininity, which she had needed but could not previously acknowledge.

Finally, note should be made of the role of the milieu staff in the treatment. They were able early in hospitalization to get her involved in the adolescent issues that are current on an adolescent service. They were very supportive of her feminine behavior and tactfully reinforced it during the second year in hospital when this was appropriate.

Two years after termination, the patient is dressing in a most feminine manner and appears to have adopted a feminine identity. It would appear that this is a unique case of a postpubertal female transsexual who has made such a gender change. It should be noted that there are no long-term follow-up studies of transsexual patients who have made such a gender identity change. Therefore, the follow-up of this patient should be significant.

\section{REFERENCES}

Baker, J. (1969). Transsexualism - Problems in treatment. Am. J. Psychiat. 125: 10, $1412-1418$.

Barlow, D. H., Reynolds, E. J., and Agras, W. S. (1973). Gender identity change in a transsexual. Arch. Gen. Psychiat. 28: 569-576.

Benjamin, H. (1966). The Transsexual Phenomenon, Julian Press, New York.

Blumer, D. (1969). Transsexualism, sexual dysfunction and temporal lobe disorder. In Green, R., and Money, J. (eds.), Transsexualism and Sex Reassignment, Johns Hopkins Press, Baltimore.

Dellaert, R., and Kunke, T. (1969). Investigations on a case of male transsexualism. $P_{s y-}$ chother. Psychosom. 17: 89-107.

Gadpaille, W. (1972). Research into the physiology of maleness and femaleness. Arch. Gen. Psychiat. 26: 193-206.

Green, R. (1970). Persons seeking sex changes: Psychiatric management of special problems. Am. J. Psychiat. 126: 11, 72-79.

Green, R. (1974). Sexual Identity Conflicts in Children and Adults, Basic Books, New York, Gerald Duckworth, London.

Hoenig, J., and Kenna, J. C. (1974). The nosological position of transsexualism. Arch. Sex. Behav. 3: 3.

Lebovitz, P. S. (1972). Feminine behavior in boys, aspects of its outcome. Am. J. Psychiat.

Money, Hampson, Hampson (1957). Imprinting and the establishment of gender role. Arch. Neurol. Psychiat. 77: 333-336.

Newman, E. (1970). Transsexualism in adolescence. Arch. Gen. Psychiat. 23: 112-121.

Newman, E., and Stoller, R. (1974). Nontranssexual men who seek sex change operation. Am. J. Psychol. 131: 4, 437-441. 
Pauley, I. (1969). The adult manifestations of female transsexualism. In Green, R., and Money, J. (eds.), Transsexualism and Sex Reassignment, Johns Hopkins University Press, Baltimore.

Socarides, C. (1970). A psychoanalytic study of the desire for sexual transformation (transsexualism): The plaster of paris man. Int. J. Psychoanal. 51: 341-349.

Stoller, R. (1968). Sex and Gender: On the Development of Masculinity and Femininity, Science House, New York.

Stoller, R. (1972). Etiologic factors in female transsexualism. Arch Sex. Behav. 2: 47-64.

Walinder, J. (1965). Transvestism, definition and evidence in favor of occasional derivation from cerebral dysfunction. Int. J. Neuropsychiat. 1: 567-573. 